УдК : $35.078 .3: 316$

\title{
ВИКРИВЛЕННЯ ІНФОРМАЦІї ЯК ТЕХНОЛОГІЯ ВПЛИВУ НА СИСТЕМУ УПРАВЛІННЯ
}

\section{Лікарчук Наталія Василівна}

доктор політичних наук, професор,

Київський національний університет ім. Тараса Шевченка, академік Академії політичних наук України

ORCID: 0000-0001-7119-439X

likarchukd@gmail.com
Надіслано:

15.10 .2020

Рецензовано:

30.10 .2020

Прийнято:

06.11 .2020

Саме проблема викривлення інформації пов'язана 3 розповсюдженням, накопиченням та обробкою даних в інформаційному суспільстві. Спотворення інформації складає певну атрибутивну рису людської комунікації, тому уміння краще розуміти й розпізнавати ії важливе практично для всіх сфер суспільного життя. Причин кривотлумачення інформації безліч, але в основному вони пов'язані 3 ворожою конкуренцією; зіткненням протилежних інтересів; підтасуванням фактів, умисним введенням суспільства в оманливий стан; «помилковими», а то й фальшивими поясненнями, висновками та інтерпретаціями; створенням «неіснуючої реальності» й для досягнення перемоги над суперником та його дискредитацією. На практиці найбільше викривлення інформації спостерігається при плануванні робіт, при усних розпорядженнях й прийнятті рішень. Хибна інформація може бути імпульсивною - це шуми різного характеру, радіохвилі, спеціальні передавальні пристрої, а також утома, неуважність, надлишкова емоційність; епізодичною, що пов'язано з висмикування інформаційних даних та інформацією поданою у відповідному часі та контексті. Виділяють й стратегічне викривлення інформації, яке направлене на поступове створення бажаного образу (держави, партії, особи). Визначено, що недостовірні повідомлення розповсюджуються основними підсистемами та їх елементами: державою, політичними партіями, спеціалізованими службами, ЗМК, корпораціями й агенціями. Ненадійні та недостовірні данні постійно «перетікають» з однієї сфери в іншу, посилюючи та загострюючи конфлікти й активізуючи протиріччя у суспільстві, створюючи кризові ситуації в державі. У статті висловлено припущення, що в Україні таке «терпиме й поблажливе» ставлення громадян до викривлення інформації органами влади, спецслужбами, політичними партіями, посадовими особами, ЗМІ зберігається через «стійкість» шаблонів поведінки і цінностей, які були властиві пострадянському простору (маємо на увазі - людину маси). 
Ключові слова: викривлення інформації; джерела інформації; система управління; державні та спеціалізовані (силові) органи; політичні партії; засоби масової інформації; корпорації; соціологічні структури.

Likarchuk Natalia, Doctor of Political Science, Professor, Taras Shevchenko National University of Kyiv, Academician of the Academy of Political Sciences of Ukraine, Kyiv, Ukraine

\section{Distortion of Information as a Management System Influence Technology}

The problem of information distortion is related to the dissemination, accumulation and processing of data in the information society. Distortion of information is a certain attributive feature of human communication, and therefore, the ability to better understand and recognize it - is important for almost all spheres of public life. There are many reasons for the distortion of information, but they are mainly related to: hostile competition; conflict of opposing interests; falsification of facts, deliberate introduction of society into a deceptive state; "Erroneous" or even false explanations, conclusions and interpretations; creating a "non-existent reality" and to achieve victory over the enemy and discredit him. In practice, the greatest distortion of information is observed in the planning of works, in oral orders and in decision-making. Distorted information can be: 1) impulsive - it is noise of various nature, radio waves, special transmitting devices, as well as: fatigue, inattention, excessive emotionality; 2) episodic, which involves the extraction of information data and information provided at the appropriate time and context. There is also a strategic distortion of information, which is aimed at the gradual creation of the desired image (state, party, individual). It is determined that inaccurate messages are distributed by the main subsystems and their elements: the state, political parties, specialized services, WMC, corporations and agencies. Unreliable and unreliable data are constantly "flowing" from one area to another: intensifying and exacerbating conflicts and intensifying contradictions in society - creating crisis situations in the state. The article suggests that in Ukraine such a "tolerant and condescending" attitude of citizens to the distortion of information by the authorities, special services, political parties, officials, the media is preserved for the "stability" of patterns of behaviour and values that were inherent in the post-Soviet space (we have in mind - a person of the mass).

Key words: distortion of information; sources of information; management system; state and specialized (power) bodies; political parties; mass media; corporations; sociological structures. 
Ликарчук Наталья Васильевна, доктор политических наук, профессор, Киевский национальный университет им. Тараса Шевченка, академик Академии политических наук Украины, г. Киев, Украина

\section{управления \\ Искажение информации как технология влияния на систему}

Именно проблема искажения информации связана с распространением, накоплением и обработкой данных в информационном обществе. Искривление информации составляет определенную атрибутивную черту человеческой коммуникации, и поэтому умение лучше понимать и распознавать ее важно практически для всех сфер общественной жизни. Причин искажения информации множество, но в основном они связаны с враждебной конкуренцией; столкновением противоположных интересов; подтасовкой фактов; умышленным введением общества в обманчивое состояние; «ошибочными», а то и фальшивыми объяснениями, выводами и интерпретациями; созданием «несуществующей реальности» и в достижении победы над соперником, его дискредитацией. На практике наибольшее искажение информации наблюдается при планировании работ, при устных распоряжениях и при принятии решений. Искаженная информация может быть импульсивной - это шумы разностороннего характера, радиоволны, специальные передаточные устройства, а также усталость, рассеянность, избыточная эмоциональность; эпизодической, которая связана с выдергиванием информационных данных и информации представленной в соответствующем времени и контексте. Выделяют и стратегическое искажение информации, которое направлено на постепенное создание желаемого образа (государства, партии, лидера). Определено, что недостоверные сообщения распространяются основными подсистемами и их элементами: государством, политическими партиями, специализированными службами, СМК, корпорациями и агентствами. Ненадежные и недостоверные данные постоянно «перетекают» из одной сферы в другую, усиливая и обостряя конфликты и активизируя противоречия в обществе, создавая кризисные ситуации в государстве. В статье высказано предположение, что в Украине такое «терпимое и снисходительное» отношение граждан к искажению информации органами власти, спецслужбами, политическими партиями, должностными лицами, СМИ сохраняется из-за «устойчивости» шаблонов поведения и ценностей, которые были присущи постсоветскому пространству (мы имеем в виду человека массы).

Ключевые слова: искажение информации; источники информации; система управления; государственные и специализированные (силовые) органы; политические партии; средства массовой информации; корпорации; социологические структуры. 


\section{Вступ}

Зростання ролі масової комунікації, розповсюдження інформаційних технологій та розростання соціальних мереж призводить до необхідності забезпечення інформаційної безпеки держави, суспільства, громадян.

Інформаційне суспільство як новий стан суспільних відносин має не лише переваги, але й несе загрози. Інформація досить часто неадекватно відображає ситуацію у державі та суспільстві. Крім того, складність проявляється ще й у зростанні джерел інформації та обновленні великої кількості даних.

Саме проблема викривлення інформації пов'язана з розповсюдженням, накопиченням та обробкою даних в інформаційному суспільстві й завжди цікавила науковців у різних галузях науки й залишалася на часі протягом усього розвитку людства.

Викривлення інформації складає певну атрибутивну рису людської комунікації, тому уміння краще розуміти й розпізнавати ії важливе практично для всіх сфер суспільного життя (Likarchuk, 2013, p. 70).

Причин викривлення інформації безліч, але в основному вони пов'язані з:

- ворожою конкуренцією;

- зіткненням протилежних інтересів;

- підтасуванням фактів, умисним введенням суспільства в оманливий стан;

- «помилковими», а то й фальшивими поясненнями, висновками та інтерпретаціями;

- створенням «неіснуючої реальності» й для досягнення перемоги над суперником та його дискредитацією.

Викривлення інформації може нанести великої шкоди будь-якій структурі, у тому числі й державі. Тому, чим більш значима інформація, тим більше вона повинна бути захищена від викривлення. Проблема кривотлумачення інформації особливо актуальна у великих організаціях зі складною управлінською структурою (Pocheptsov, 2011).

Це поняття ми часто зустрічаємо в соціальних мережах, але не надаємо йому належного значення, хоча за останні роки значна кількість робіт присвячена дослідженню багатьох аспектів феномену спотворення інформації, у різноманітних її проявах та багатоманітності назви.

\section{Аналіз останніх досліджень і публікацій}

До зарубіжних вчених, які під різними кутами зору досліджували питання викривлення інформації слід віднести: А. Белла, М. Вайкоффа, Дж. Джоунза, Д. Дора, Д. Канемана, Ж. Піаже, Е. Тверскі, С. Херреча, Г. Філо.

Серед українських дослідників, які належать до різних наукових напрямів дослідження цієї проблематики, слід назвати О.Антонова, О. Воронова, Н. Зубара, Л. Гонтаренко, К. Каландарова, В. Кириченко, О. Курбан, 
Г. Лучик, О. Павлова, 3. Портико, Г Почепцова, В. Шлапакова, А. Яфонкіна. Так, Л. Гонтаренко вважає, що викривлення інформації дозволяє створювати визначене відображення дійсності в суспільній свідомості, у якій викривленні факти будуть часткою реальності (Hontarenko, 2017, p. 20).

\section{Виділення невирішених раніше частин загальної проблеми}

У світлі вищесказаного, наше дослідження орієнтоване на встановлення значимості зміни, викривлення інформації як технології впливу на систему управління.

\section{Формулювання цілей статті}

Виявити вплив викривлення інформації як технології впливу на систему управління.

\section{Виклад основного матеріалу дослідження}

На практиці найбільше викривлення інформації спостерігається при плануванні робіт, при усних розпорядженнях й при прийнятті рішень (Yafonkin, 2017, р. 156).

Викривлена інформація може бути:

- імпульсивним - це шуми різнобічного характеру, радіохвилі, спеціальні передавальні пристрої, а також утома, неуважність, надлишкова емоційність тощо;

- епізодичним, яке пов'язане з висмикування інформаційних даних та інформацією поданою у відповідному часі та контексті.

Однак, виділяють й стратегічне спотворення інформації, яке направлене на поступове створення бажаного образу (держави, партії, особи).

Часто викривлення інформації відбувається не 3 вини джерела інформації, а в процесі іï передачі, тобто джерелом дезінформації стає сам канал передачі.

Інший аспект можливого викривлення інформації - різне тлумачення одних і тих же слів у залежності від інтонації, розділових знаків, контексту та асоціативних станів, які виникають у людей на одні і ті ж слова. Існує така категорія людей, яка так вибудовує фрази, що подаючи заздалегідь неправдиву інформацію, формально залишаються правдивими.

Недостовірні повідомлення, які розповсюджуються основними підсистемами та їх елементами (державою, політичними партіями, спеціалізованими службами, ЗМК, корпораціями, агенціями) пронизане все суспільство. Ненадійні та недостовірні данні постійно «перетікають» $з$ однієї сфери в іншу, посилюючи та загострюючи конфлікти й активізуючи протиріччя у суспільстві, створюючи кризові ситуації в державі.

Викривлення інформації спирається на використання сучасних технологій «вживлення» й узвичаєння їх в систему управління, які стали невід'ємним її компонентом. Виділяються підсистеми спотворення інформації 
про події, процеси, види діяльності. Підсистеми та їх елементи взаємодіють і впливають одна на одну, забезпечують спроможність зберегти й удосконалити систему.

Як правило, одні підсистеми та їх елементи діють постійно й зазіхають на всевладдя, домінування та всеосяжність, а інші - набирають сили й активізуються в окремі періоди.

Так, підсистеми викривлення інформації змушені посилюватися, щоб зберегти свою могутність, так як загрозу їх владі несе розповсюдженість різноманітних даних через мережеві системи.

Серед переліку підсистем, які здійснюють найбільший вплив на суспільство є держава. Вона здатна стати «лідером» у викривленні та «імітації» турботи у створенні умов для інвестицій у всіх сферах життєдіяльності суспільства. Розповсюдження недостовірної інформації дозволяє органам влади приховувати неефективність управління посилаючись на підступи зовнішніх сил чи формуючи образи ворогів.

Крім того, держава здійснює:

- вплив на формування структури системи викривлення інформації;

- визначає напрям діяльності підсистеми та їх елементів;

- окреслює першочерговість і невідкладність одних питань, зменшує значення інших, в залежності від ситуації, змінює ставлення до роботи підсистем та їх елементів (Evdokymov, 2015, p. 122).

Маючи у наявності особливі, часто протилежні інтереси, держава «втягується» у процес суперництва, нарощуючи пропаганду, яка базується на використанні візуальних, риторичних, символічних засобів і технологій, що направленні на нав'язування громадянам певного (вигідного державі) уявлення про події, які відбуваються у світі.

На думку Е. Тоффлера, «політична машина при прийнятті рішень «затоплена» недостовірними даними й зіштовхується з невідомою небезпекою» (Toffler, 2000, p.622). Але певні політичні кола впевнені у такому підході, посилаючись на те, що підтримують стабільність у суспільстві та координують діяльність суб'єктів політичної системи, забезпечують національну безпеку.

Але найчастіше, викривлення інформації використовується для укріплення влади у боротьбі за повноваження, статуси і ресурси. Щоб такий процес був успішним, розробляють технології, визначають шаблони сприйняття повідомлень масовою свідомістю й за допомогою такої комунікації формується вигадана (надумана) реальність (Lylleker, 2010, p. 230). Управління за допомогою спотвореної інформації розширює можливості державних інституцій та окремих політиків інтерпретувати (пояснювати) власну діяльність у вигідному їм світі. 
Елементом підсистеми $є$ й спеціалізовані служби. 3 одного боку вони ведуть боротьбу з тероризмом, злочинністю, з іншого - відстоюють інтереси пануючого в суспільстві суб'єкта й підтримують законність його дій. Так, ще однією їх особливістює те, що вони не можуть контролювати органи законодавчої і виконавчої влади, крім того, вони здатні дезінформувати учасників соціально-політичного процесу.

Викривлення інформації спецслужбами, може бути основою для прийняття рішень й застосування репресивних засобів по відношенню до опозиційних сил.

Ще одну підсистему викривлення інформації формують політичні партії. Як правило, в ході політичної боротьби вони включають у свої програми/проєкти повідомлення, які виконати неможливо (те, що ми називаємо політичним популізмом). Крім того, часто, по-своєму трактують цілі та задачі конкурентів, приписують їм «діяння», які ті ніколи не здійснювали. Зазвичай, така хибна інформація (через маніпулятивні технології) найчастіше застосовується під час виборчих кампаній.

Так, державні органи і політичні партії часто співпрацюють 3 політичними консультантами (експертами, аналітиками), які здійснюють технологічний, аналітичний та організаційний супровід політичних кампаній за допомогою створення і реалізації технологій, які містять маніпулятивний вплив через навмисне спотворення того, що відбувається в електоральному просторі. Такі політичні агенції сприймають політику як бізнес, надаючи «допомогу» тим претендентам на владні повноваження, які не здатні виконати передвиборчі обіцянки (а їх більшість на українському політичному полі).

Для всіх трьох складових - держави, політичних партій і політичних консультантів (експертів, аналітиків) - цінним і вартісним $є$ кооперація з такою підсистемою як ЗМІ.

ЗМІ завжди приваблювали такі структури, адже вони часто:

- офірують (жертвують) достовірною інформацією 3 власних кон'юктурних міркувань;

- сприяють суб’єктам політики у досягненні цілей «розвінчувати» та компрометувати їх конкурентів.

Варто зауважити, що впливові ЗМІ часто можуть висвітлювати конфлікти у регіонах, розглядаючи події у «вигідному» ракурсі для замовника такої інформації.

Найбільший вплив здійснює телебачення, пропонуючи громадянам спрощенні варіанти трактування подій. Населення, яке не бажає (або не здатне) шукати відповіді на складні проблеми, така ситуація повністю влаштовує. Очевидно, мозаїчність, фрагментарність, калейдоскопічність й марнославство у тлумаченні подій влаштовує й задовольняє населення. Адже аналіз 
ситуації вимагає від громадян раціонального мислення, аналітичного сприйняття фактів, виявлення причинно-наслідкових зв'язків і причин тих явищ, які відбуваються у соціумі.

Від аналогічних недоліків потерпають й соціологічні структури, адже часто працюють на замовлення політичних суб'єктів (найбільше спотворення інформації відбувається під час виборчих кампаній, так звані рейтинги політиків, політичних партій). Досить велика частка кривотлумачення інформації припадає на корпорації (спілки, товариства, асоціації, компанії). Такі структури заради отримання надприбутків за допомогою хибної інформації підштовхують громадян (суспільство) в оманливий світ відносно якості товарів і послуг. Крім того, такі структури можуть вводити в оману інвесторів. Часто інтереси держави і корпорацій, які пропонують громадянам недостовірну інформацію, можуть співпадати (Bogl, 2011,p. 119).

У сучасному світі держави спроможні поєднувати антитетичні (полярні) компоненти, які складаються з окремих протилежних компонентів (наприклад, красивого i потворного, демократичного й плутократичного, відкритого й завуальованого).

Як показує досвід, частина громадян вважає, що за певних умов, держава може «замовчувати» питання, що пов'язані 3 державними інтересами та національною безпекою, навіть за умови, приховування «прорахунків» органів державної влади, які призвели суспільство до економічної «прірви», соціального «зубожіння» населення, конфліктів чи кризових ситуацій.

Ми припускаємо, що в Україні таке «терпиме й поблажливе» ставлення громадян до викривлення інформації органами влади, спецслужбами, політичними партіями, посадовими особами, ЗМІ зберігається через «стійкість» шаблонів поведінки і цінностей, які були властиві пострадянському простору (маємо на увазі - людину маси).

Зазначимо, що достовірна інформація часто може викликати «тривогу» у людини й паніку у суспільства. Особа не в змозі перебороти/«подолати» таку інформацію: вона ï лякає, травмує й шокує. Крім того, від буденної реальності людина втомлюється, тому шукає джерела, які не лише надавали б їй таких повідомлень, але й не суперечили б їі стереотипам. У свою чергу, стереотипи і уявлення, які склалися у її свідомості, спрощують формування ілюзії про те, що зазначені підсистеми застосовують усі можливі технології для інноваційного розвитку суспільства.

Так, під впливом викривленої інформації зароджується індиферентне (відчужене, апатичне) ставлення до важливих процесів, що відбуваються у суспільстві. Так, громадяни знаходячись під постійним, наскрізним i безперервним контролем цих підсистем не мають бажання добровільно брати участь у вирішенні навіть власних проблем. Як правило, чим простіше 
тлумачення (розуміння) процесів, що відбуваються, тим громадянам легше сприймати інформацію про події, явища, інциденти, катастрофи, катаклізми та конфлікти.

Саме через конфлікти (внутрішні, міжнародні) чітко проявляється «упорядкований і організований» характер недостовірної інформації (Likarchuk, 2014 , p. 359). Систему викривлення інформації консолідують, спаюють органи влади. Так, недостовірну інформацію можуть розповсюджувати й президенти (Evdokymov, 2015, р.125). Сучасна система управління, притримується такої позиції, коли використання спотвореної інформації може підтримувати порядок інформаційного насилля, й на застосування таких технологій витрачатиметься менше коштів, ніж на утримання правоохоронних органів.

У разі, коли частина членів суспільства незадоволена великими об'ємами викривленої інформації, послабити таку ситуацію може «викид» населенню достовірних повідомлень.

\section{Висновки}

Створювати умови, інколи вимагати надавати достовірну інформацію здатні групи інтелектуальної, економічної, наукової еліти, громадські організації та окремі активісти. Не виключається можливість формування «культури меншої частини громадян», які спроможні успішно вести пошук інформації, якій довіряють (наприклад, через соціальну мережеву систему). Але пропагандистські повідомлення, все ж переважають над іншими видами інформації. Зазначимо, що будь-яку вигадку можна видати за істину, а вкидання чуток замінити фактами.

Очікування обіцяного може не здійснитися, а соціум обговорюватиме його наслідки через здогадки припущення спотворення, перекручування реальності. Тому часто виникають кризи, або суспільство (наприклад, українське) може перебувати в постійній кризовій ситуації. Кризи відбуваються зазвичай через те, що об’єм викривленої інформації різко збільшується, а пласт достовірної інформації скорочується, що помітно через погіршення економічної ситуації, збільшення безробіття та зниження доходів громадян.

\section{References:}

1. Bogl, D. (2011). Bitva za dushu kapitalizma [The battle for the soul of capitalism]. Moscow: Gaidai Institute Publishing House.

2. Evdokimov, V.A. (2015.) 'Sistemnoe iskazhenie soobshchenii v postinformatsionnom obshchestve' [Systemic distortion of messages in the post information society]. Nauka o cheloveke : gumanitarnye issledovaniya [Human Science: Humanities Research], no. 1(19), pp. 120-127.

3. Hontarenko, L. O. (2017). 'Vykrevlennia informatsii yak vplyv na hromadski uiavlennia pro viinu' [Distortion of information as an impact on public perceptions of 
war ]. Ukrainskyi psykholohichnyi zhurnal [Ukrainian Psychological Journal], no.1, pp. 17-25.

4. Likarchuk, D. S. (2014). 'Osoblyvosti konfliktu v politychnii sferi' [Specifics of Conflict in Political Sphere]. Hileia [Gilea], issue 83, pp. 358-361.

5. Likarchuk, N. V. (2013). 'Bazovi semiotychni modeli komunikatsii' [Basic semiotic models of communication]. Politychni nauky ta metodyka vykladannia sotsialno-politychnykh dystsyplin. Seriia 22 [Political sciences and methods of teaching socio-political disciplines. Series 22], issue 16, pp. 69-74.

6. Lylleker, D. (2010). Politicheskaya kommunikatsiya. Klyuchevye kontsepty [Political communications. Key concepts]. Moscow: Gumanitarnyi Tsentr.

7. Pocheptsov, H. (2011). 'Chomu i yak vidbuvaietsia vykryvlennia realnosti v informatsiinomu prostori' [Why and how is the distortion of reality in the information space]. Media Sapiens, [online]. Available at: https://ms.detector.media/manipulyatsii/post/9079/2020-09-09-chomu-i-yakvidbuvaetsya-vikrivlennya-realnosti-v-informatsiinomu-prostori/.

8. Solov'ev, A. I. (2015). 'Gosudarstvennye resheniya: kontseptual'nyi prostor i tupiki teoretizatsii' [Government decisions: conceptual space and theorizing dead ends]. Polis (Politicheskie issledovaniya) [Polis (Political Studies)], no. 3, pp. 127-146.

9. Toffler, E. (2000). Tretia Khvylia [The Third Wave]. Kyiv: Vsesvit Publishing House.

10. Yafonkin, A. O. (2017). 'Obih nepravdyvoi informatsii v zasobakh masovoi komunikatsii Ukrainy' [Circulation of false information in the media of Ukraine]. Mizhnarodnyi yurydychnyi visnyk: aktualni problemy suchasnosti (teoriia i praktyka) [International Legal Bulletin: current issues (theory and practice)], issue 2-3, no. 6-7, pp. 153-158.

(С) Лікарчук Н. В., 2020 